\title{
PENGARUH LAYANAN INFORMASI KARIER TERHADAP KEMAMPUAN PERENCANAAN KARIER SISWA KELAS XI SMA NEGERI 2 CEPU
}

\author{
Yari Dwikurnaningsih \\ Program Studi 1 S1 Bimbingan dan Konseling \\ FKIP Universitas Kristen Satya Wacana \\ Dwitania Ramadani Adiputri \\ Alumni Program Studi 1 Bimbingan Konseling \\ FKIP Universitas Kristen Satya Wacana
}

\begin{abstract}
ABSTRAK
Penelitian ini bertujuan untuk menguji signifikansi peningkatan kemampuan perencanaan karier siswa kelas XI SMA Negeri 2 Cepu melalui layanan informasi karier. Metode penelitian yang digunakan adalah eksperimen dengan desain eksperimen semu. Subjek penelitian ini 37 siswa yang kemampuan perencanaan kariernya sedang, rendah dan sangat rendah. Subjek penelitian dibagi menjadi 2 kelompok yaitu kelompok eksperimen dan kelompok kontrol. Kelompok eksperimen merupakan kelompok yang diberi perlakuan yaitu layanan informasi karier, sedangkan kelompok kontrol tidak diberi perlakuan. Kedua kelompok tersebut diuji homogenitas yang hasilnya $\mathrm{p}=0.616$ ( $\mathrm{p}>0.050)$ artinya antara kelompok kontrol dan eksperimen memiliki varians yang sama atau homogen sehingga kedua kelompok tersebut bias dijadikan obyek penelitian. Teknik Pengumpulan data menggunakan skala yaitu skala sikap perencanaan karier yang diadopsi dari Anggraeni (2012) yang disusun berdasarkan teori Parsons dan Williamsons. Skala sikap perencanaan karier terdiri dari 48 item pernyataan, setelah uji validitas dan reliabilitas, seluruh item dinyatakan valid dan instrumen dinyatakan reliabel. Teknik analisis data yang digunakan adalah Mann Whitney dengan bantuan menggunakan program SPSS 16.0. Hasil analisa yang dilakukan diperoleh skor $\mathrm{Z}=-5.197$ dan Asymp.Sig.(2-tailed) $\mathrm{p}=0.000<0.050$. Berdasarkan hasil tersebut dapat disimpulkan bahwa ada perbedaan yang signifikan kemampuan perencanaan karier kelompok eksperimen dengan kelompok Kontrol. Selanjutnya dilihat dari skor pretest dan postest kelompok eksperimen menunjukkan peningkatan sebesar 8,44. Berdasarkan hasil analisa data dapat disimpulkan ada pengaruh layanan informasi karier terhadap kemampuan perencanaan karier siswa kelas XI SMA Negeri 2 Cepu.
\end{abstract}

Kata Kunci: Kemampuan Perencanaan Karier, Layanan Informasi Karier

\section{PENDAHULUAN}

Setiap orang pada umumnya memerlukan lapangan kerja untuk bertahan hidup. Di dalam masyarakat secara luas terdapat berbagai jenis pekerjaan, tetapi pekerjaanpekerjaan yang dijabat tidak semuanya memperoleh hasil serta membahagiakan sebagaimana yang menjadi tujuan hidup seseorang. Dalam perkembangan karier seseorang dipengaruhi oleh faktor internal dan eksternal.

Ginzberg menyatakan bahwa siswa SMA berada pada tahap tentatif dimana siswa harus sudah mampu memikirkan atau merecanakan kariernya berdasarkan minat dan nilai-nilai atau potensi yang dimiliki siswa tersebut (dalam Winkel dan Hastuti, 
2006). Kenyataan yang ada di lapangan banyak siswa kelas XI SMA Negeri 2 Cepu yang belum merencanakan kariernya secara matang. Sebesar 60 persen dari 62 siswa yang masih belum matang dalam merencanakan kariernya. Data tersebut dapat di lihat pada tabel berikut:

Tabel 1 Kemampuan Perencanaan Karier Siswa Kls.XI SMA Negeri 2 Cepu Sebelum Eksperimen

\begin{tabular}{clcc}
\hline NO & KATEGORI & JML & PERSEN \\
\hline 1. & Sangat rendah & 11 & 18 \\
2. & Rendah & 13 & 21 \\
3. & Sedang & 13 & 21 \\
4. & Tinggi & 13 & 21 \\
5. & Sangat tinggi & 12 & 19 \\
\hline Jumlah & & $\mathbf{6 2}$ & $\mathbf{1 0 0}$ \\
\hline
\end{tabular}

Perencanaan karier merupakan salah satu aspek yang penting dalam perkembangan karier siswa. Kecakapan dalam mengambil keputusan merupakan tujuan utama dari perencanaan karier yang harus ditempuh oleh setiap siswa. Menurut Walgito (2004), siswa kelas XI berada dalam masa remaja yang merupakan masa peralihan dari masa anakanak ke masa dewasa. Pada umumnya, para siswa tersebut belum dapat mandiri sehingga masih memerlukan bantuan dari orang lain untuk menuju kemandirian, termasuk kemampuan dalam perencanaan karier. Sehubungan dengan hal itu, para siswa memerlukan bimbingan dalam hal karier untuk menyiapkan perencanaan karier yang matang.

Bimbingan dan Konseling membantu siswa dalam hal karier atau disebut dengan bimbingan karier. Bimbingan karier dapat diberikan melalui berbagai cara dan bentuk layanan salah satunya yakni layanan informasi karier, menurut Prayitno dan Amti (2009) layanan informasi merupakan layanan yang diberikan untuk membekali seseorang supaya memperoleh berbagai pengetahuan mengenai berbagai hal seperti informasi pen- didikan, karier atau pun tentang pendidikan dan karier yang berhubungan. Adanya layanan informasi karier diharapkan dapat menimbulkan kemantapan dalam perencanaan karier siswa.

\section{Rumusan Masalah}

Apakah layanan informasi karier berpengaruh secara signfikan terhadap kemampuan perencanaan karier siswa kelas XI SMA Negeri 2 Cepu?

\section{Tujuan Penelitian}

Tujuan penelitian ini adalah mengetahui pengaruh layanan informasi karier terhadap kemampuan perencanaan karier siswa kelas XI SMA Negeri $2 \mathrm{Cepu.}$

\section{LANDASAN TEORI}

\section{Kemampuan Perencanaan Karier}

Parsons dan Williamson (dalam Winkel \& Hastuti, 2006) seseorang dapat menemukan jabatan yang cocok baginya dengan cara mengkorelasikan kemampuan, potensi dan wujud minat yang dimilikinya dengan kualitaskualitas yang secara obyektif dituntut bila akan memegang jabatan tertentu. Pandangan ini terutama menyoroti bagaimana seseorang akan membuat pilihan karier (vocational choice) yang dapat dipertanggungjawabkan. Kegunaan dari perencanaan karier yang matang adalah meminimalkan kemungkinan dibuat kesalahan yang berat dalam memilih diantara alternatif-alternatif yang tersedia. Seandainya siswa hanya memikirkan tujuan jangka pendek saja, tanpa jelas menghubungkan suatu tujuan jangka panjang (kariernya dimasa depan) terdapat kemungkinan bahwa suatu tujuan jangka pendek yang telah dicapai ternyata tidak selaras dengan tujuan jangka panjang. 
Faktor-faktor menurut Williamson yang diperlukan dalam membuat perencanaan karier siswa (Winkel \& Hastuti, 2006) yaitu informasi tentang diri sendiri, data tentang keluarga dekat dan informasi tentang lingkungan hidup yang relevan bagi perencanaan karier, khususnya informasi pendidikan dan informasi jabatan, yang bersama-sama dikenal dengan informasi karier.

Menurut Parsons dan Williamson (dalam Anggraeni, 2012) aspek-aspek perencanaan karier yaitu:

1. Aspek yang pertama yaitu pemahaman diri yang meliputi ideal (nilai-nilai hidup), cita-cita dalam kehidupan, minat-minat, kemampuan otak, bakat khusus dan sifatsifat kepribadian.

2. Aspek yang kedua yaitu pengenalan lingkungan keluarga yang meliputi kemampuan di bidang ekonomi, keadaan dibidang taraf pendidikan dan harapan orang tua dan saudara.

3. Aspek yang ketiga yaitu informasi tentang kenyataan lingkungan (program studi dan bidang pekerjaan), yang meliputi memiliki cita-cita hidup, mengenal jenis sekolah lanjutan, mampu memilih sekolah lanjutan, mengikuti pengembangan diri dengan bakat, mengetahui gambaran tentang jenis pekerjaan, mengetahui tentang informasi kursus dan keterampilan, mengetahui dalam hal melamar pekerjaan dan bidang pekerjaan yang dibutuhkan di daerah tertentu.

\section{Layanan Informasi Karier}

Menurut Dessy dan Nursalim (2002) layanan informasi karier yaitu pemberian informasi (seperti informasi pendidikan dan informasi jabatan) yang dapat digunakan sebagai bahan pemikiran sebaik-baiknya untuk dijadikan bahan pertimbangan dalam mengambil keputusan dan pertimbangan lainya. Layanan informasi karier merupakan layanan yang diberikan kepada siswa untuk membantu siswa mendapat pengetahuan serta pemahaman tentang dirinya dan mengenai karier yang meliputi informasi tentang Perguruan Tinggi, dunia kerja serta syaratsyarat yang diperlukan sehingga siswa mampu merencanakan dan menentukan keputusan yang tepat untuk kariernya.

Prayitno dan Amti (2009), mengungkapkan ada tiga alasan utama mengapa pemberian informasi perlu diselenggarakan, yaitu:

a. Membekali individu dengan berbagai pengetahuan tentang lingkungan yang diperlukan untuk memecahkan masalah yang dihadapi berkenaan dengan lingkungan sekitar, pendidikan, jabatan, maupun sosial budaya. Dalam masyarakat yang serba majemuk dan semakin kompleks, pengambilan keputusan yang dapat dipertanggungjawabkan sebagian terletak di tangan individu itu sendiri. Dalam hal ini, layanan informasi berusaha merangsang individu untuk dapat secara kritis mempelajari berbagai informasi berkaitan dengan hajat hidup perkembangannya.

b. Memungkinkan individu dapat menentukan arah hidupnya "kemana dia ingin pergi“. Syarat dasar untuk dapat menentukan arah hidup adalah apabila ia mengetahui apa (informasi) yang harus dilakukan serta bagaimana bertindak secara kreatif dan dinamis berdasarkan atas informasi yang diberikan itu. Individu diharapkan dapat membuat rencana dan keputusan tentang masa depannya serta bertanggung jawab atas rencana dan keputusan yang dibuatnya itu.

c. Setiap individu adalah unik. Keunikan itu akan membawakan pola-pola pengambilan keputusan dan bertindak yang berbedabeda disesuaikan dengan aspek-aspek 
kepribadian masing-masing individu. Pertemuan antara keunikan individu dan variasi kondisi yang ada di lingkungan dan masyarakat yang lebih luas, diharapkan dapat menciptakan berbagai kondisi baru baik bagi individu yang bersangkutan maupun bagi masyarakat, yang semuanya itu sesuai dengan keinginan individu dan masyarakat. Dengan demikian akan terciptalah dinamika perkembangan individu dan masyarakat berdasarkan potensi positif yang ada pada diri individu dan masyarakat.

\section{METODE PENELITIAN}

Jenis penelitian yang digunakan adalah penelitian eksperimen semu. Penelitian eksperimen ini menggunakan dua kelompok yaitu kelompok eksperimen dan kelompok kontrol. Kelompok eksperimen adalah kelompok yang akan diberi perlakuan (Layanan informasi karier). Kelompok kontrol adalah kelompok yang tidak diberi perlakuan sama sekali. Baik kelompok eksperimen yang diberi perlakuan maupun kelompok kontrol yang tidak diberi perlakuan keduanya diberi tes awal (pretest) dan tes akhir (posttest). Model yang digunakan dalam penelitian ini digambarkan sebagai berikut:

\begin{tabular}{l|ccc|} 
Group : & Pretest & Treatment & Postest \\
Ex.Group & $\mathrm{T} 1$ & $\mathrm{X}$ & $\mathrm{T} 2$ \\
Ctr.Group & $\mathrm{T} 1$ & - & $\mathrm{T} 2$ \\
\cline { 2 - 4 } & & &
\end{tabular}

Keterangan:

$\mathrm{T} 1$ : Tes awal/pretest

T2 : Tes akhir/posttest

$\mathrm{X}$ : Perlakuan/Treatment (Layanan informasi karier)

Pretest diberikan untuk mengukur mean kedua kelompok eksperimen dan kelompok kontrol. Kemudian pada kelompok eksperimen dikenai variabel perlakuan $\mathrm{X}$ untuk jangka waktu tertentu dan diberikan postest untuk mengukur adakah perbedaan antara sebelum dan setelah diberikan treatment.

Subjek penelitian ini adalah 37 siswa kelas XI kelas IPS 2 dan IPS 3 SMA Negeri 2 Cepu. Kelas IPS 2 berjumlah 18 siswa, sedangkan kelas IPS 3 berjumlah 19 siswa. Subjek penelitian dipilih dengan pertimbangan subjek penelitian berada pada kategori kemampuan perencanaan karier sedang, rendah dan sangat rendah. Sebelum eksperimen, dilakukan uji homogenitas untuk mengetahui apakah kedua kelompok tersebut homogeny. Sebagai syarat dalam eksperimen, kedua kelompok tersebut dalam kondisi awal atau sebelum mendapatkan perlakuan harus homogeny kemampuan perencanaan kariernya. Hasil uji homogenitas dipaparkan pada tabel 2 .

Tabel 2 Hasil Uji Homogenitas

\begin{tabular}{|c|c|c|c|}
\multicolumn{4}{c}{ Ranks } \\
\hline Kelompok & N & $\begin{array}{r}\text { Mean } \\
\text { Rank }\end{array}$ & Sum of Ranks \\
\hline NPK Eksperimen & 19 & 19.87 & 377.50 \\
Kontrol & 18 & 18.08 & 325.50 \\
Total & 37 & & \\
\hline
\end{tabular}

\section{Test Statistics ${ }^{b}$}

\begin{tabular}{|l|r|}
\hline & NPK \\
\hline Mann - Whitney U & 154.500 \\
Wilcoxon W & 325.500 \\
Z & -.502 \\
Asymp. Sig. (2 - tailed) & .616 \\
Exact Sig.[*(1-tailed Sig.)] & $.620 \mathrm{a}$ \\
\hline
\end{tabular}

a. Not corrected for ties.

b. Grouping Variable: kelompok

Tabel 2 menunjukkan hasil uji homogenitas antara kelompok kontrol dan kelompok eksperimen, yaitu Asymp. Sig. (2- 
tailed $)=0,616$. Mean rank kelompok eksperimen 19,87 dan mean rank kelompok kontrol 18,08. Hasil Asymp. Sig. (2-tailed)= $0,616>0,050$, yang berarti bahwa antara kelompok kontrol dan kelompok kontrol homogen (mempunyai varians yang sama). Dikatakan homogen karena nilai Signifikansi atau nilai probabilitas $p>0,050$. Dengan demikian, kedua kelompok tersebut dapat dijadikan sebagai subyek penelitian.

Teknik pengumpulan data yang digunakan dalam penelitian ini yaitu menggunakan skala sikap perencanaan karier yang diadopsi dari Anggraeni (2012) dan disusun berdasarkan teori Parsons dan Williamsons, dengan jumlah item sebanyak 48 item pernyataan. Skala sikap tersebut dirancang menggunakan model skala likert (likert scale) dengan 4 pilihan jawaban, yaitu sangat sesuai (SS), sesuai (S), kurang sesuai (KS), dan tidak sesuai (TS). Teknik analisis data yang digunakan dalam penelitian ini adalah uji Mann Whitney.

Tindakan atau perlakuan yang diberikan kepada kelompok eksperimen berupa layanan informasi karier. Materi layanan informasi karier dikembangkan berdasarkan aspek-aspek perencanaan karier menurut Parsons dan Williamson seperti yang dipaparkan pada tabel 3.

\section{HASIL PENELITIAN DAN PEMBAHASAN}

Setelah kelompok eksperimen diberi perlakuan dengan layanan informasi karier sebanyak 8 kali, diperoleh perbedaan skor kemampuan perencanaan karier kelompok eksperimen dan kelompok kontrol. Tabel 4 menunjukkan skor kemampuan perencanaan karier kelompok eksperimen dan kontrol setelah eksperimen.

Berdasarkan pada tabel 4, kemampan perencanaan karier kelompok eksperimen lebih tinggi dibandingkan kelompok kontrol. Kelompok eksperimen setelah mendapat perlakuan kemampuan perencanaan kariernya 5 persen dalam kategori sedang, 79 persen dalam kategori tinggi dan 16 persen dalam kategori sangat tinggi. Tidak ada siswa yang berada pada kategori rendah dan sangat rendah. Untuk mengetahui signifikansi perbedaan tersebut selanjutnya dilakukan pengolahan data dengan menggunakan teknik Mann Whitney yang ditampilkan pada Tabel 5 .

Tabel 3 Materi Layanan Informasi Karier

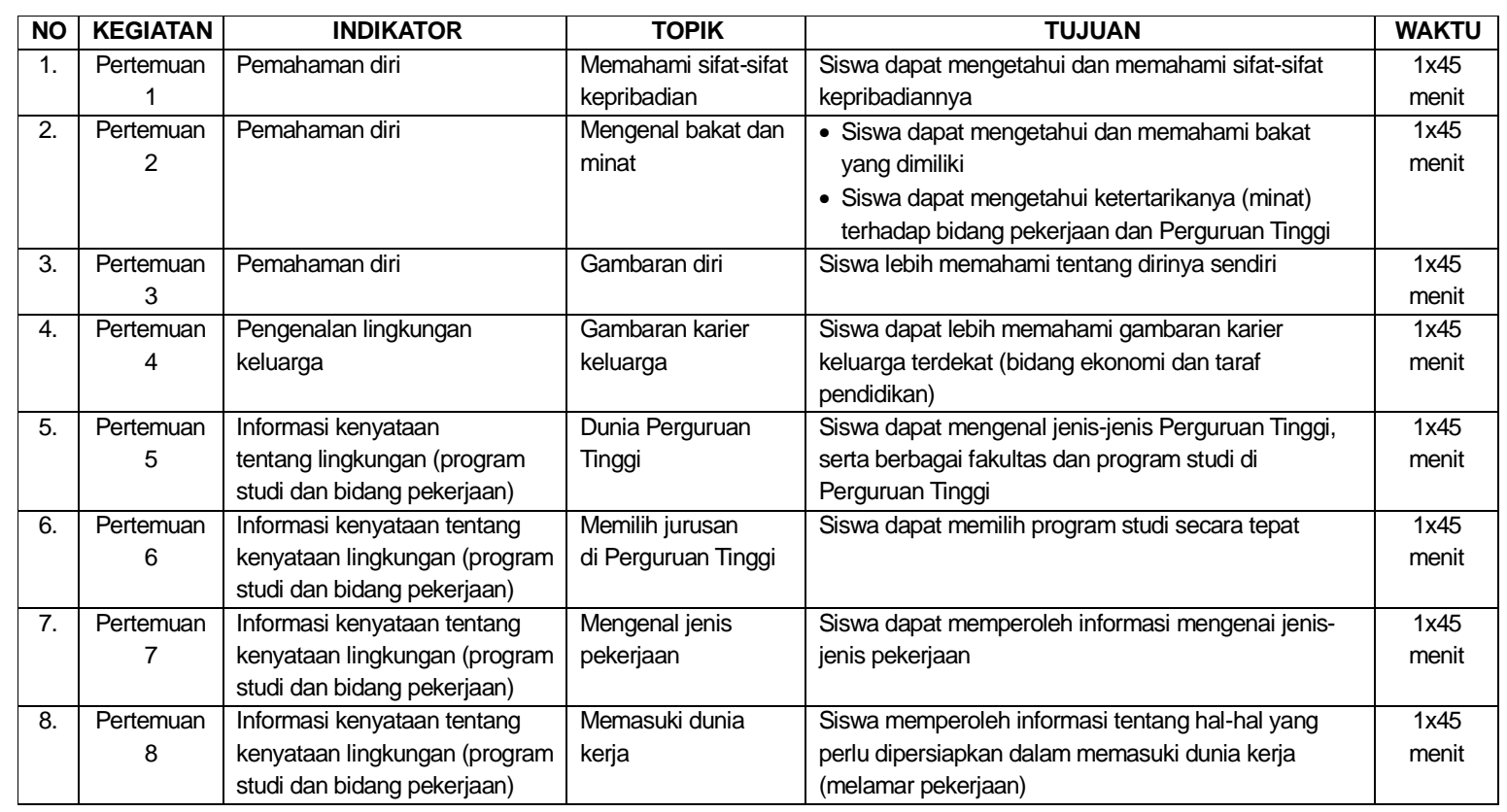


Tabel 4 Hasil Posttest Kemampuan Perencanaan Karier Pada Kelompok Eksperimen dan Kontrol

\begin{tabular}{|c|c|c|c|c|c|c|}
\hline \multirow[t]{2}{*}{ No } & \multicolumn{2}{|c|}{ Nama } & \multicolumn{2}{|c|}{ Skor } & \multicolumn{2}{|c|}{$\begin{array}{c}\text { Kategori Kemampuan } \\
\text { Perencanaan Karier }\end{array}$} \\
\hline & Eksperimen & Kontrol & Eksperimen & Kontrol & Eksperimen & Kontrol \\
\hline 1 & AY & $\mathrm{AZ}$ & 159 & 127 & 4 & 3 \\
\hline 2 & $\mathrm{AL}$ & AS & 147 & 74 & 4 & 1 \\
\hline 3 & AR & $\mathrm{BP}$ & 137 & 97 & 4 & 2 \\
\hline 4 & $\mathrm{CF}$ & DA & 163 & 69 & 4 & 1 \\
\hline 5 & DF & DT & 140 & 98 & 4 & 2 \\
\hline 6 & DI & FM & 160 & 124 & 4 & 3 \\
\hline 7 & DV & $\mathrm{FC}$ & 169 & 66 & 5 & 1 \\
\hline 8 & EL & $\mathrm{KH}$ & 144 & 90 & 4 & 2 \\
\hline 9 & $\mathrm{FF}$ & MA & 138 & 73 & 4 & 1 \\
\hline 10 & IY & NA & 166 & 105 & 5 & 2 \\
\hline 11 & LS & NY & 145 & 75 & 4 & 1 \\
\hline 12 & MA & PD & 154 & 117 & 4 & 3 \\
\hline 13 & $\mathrm{MN}$ & $\mathrm{RB}$ & 135 & 97 & 4 & 2 \\
\hline 14 & $\mathrm{NU}$ & $\mathrm{RA}$ & 138 & 104 & 4 & 2 \\
\hline 15 & $\mathrm{RN}$ & $\mathrm{RD}$ & 129 & 76 & 3 & 1 \\
\hline 16 & SN & SN & 177 & 119 & 5 & 3 \\
\hline 17 & $\mathrm{SR}$ & SY & 144 & 123 & 4 & 3 \\
\hline 18 & TW & $\mathrm{TL}$ & 146 & 126 & 4 & 3 \\
\hline 19 & YT & & 136 & & 4 & \\
\hline \multicolumn{3}{|c|}{ Rata-rata } & 148,78 & $\mathbf{9 7 , 7 7}$ & & \\
\hline \multicolumn{3}{|c|}{ Kategori } & \multicolumn{2}{|c|}{ Eksperimen } & \multicolumn{2}{|c|}{ Kontrol } \\
\hline \multicolumn{3}{|c|}{1 : Kategori Sangat Rendah } & \multicolumn{2}{|l|}{-} & \multicolumn{2}{|c|}{$33,33 \%$} \\
\hline \multicolumn{3}{|c|}{2 : Kategori Rendah } & \multicolumn{2}{|l|}{-} & \multicolumn{2}{|c|}{$33,33 \%$} \\
\hline \multicolumn{3}{|c|}{3 : Kategori Sedang } & \multicolumn{2}{|c|}{$5 \%$} & \multicolumn{2}{|c|}{$33,33 \%$} \\
\hline \multicolumn{3}{|c|}{4 : Kategori Tinggi } & \multicolumn{2}{|c|}{$79 \%$} & \multicolumn{2}{|c|}{-} \\
\hline \multicolumn{3}{|c|}{5 : Kategori Sangat Tinggi } & \multicolumn{2}{|c|}{$16 \%$} & \multicolumn{2}{|c|}{-} \\
\hline
\end{tabular}

Pada pengolahan hasil posttest kelompok eksperimen dan kontrol diperoleh hasil uji statistik dengan teknik analisis Mann Whitney yaitu Z= -5.197 dan Asymp.Sig.(2tailed) $\mathrm{p}=0.000<0.050$, hasil tersebut menunjukan bahwa ada perbedaan yang sangat signifikan antara kelompok eksperimen dan kelompok kontrol dalam hal perencanaan karier setelah kelompok eksperimen diberikan layanan informasi karier. Mean rank kelompok eksperimen 28.00 dan mean rank kelompok kontrol 9.50. Selisih mean rank antara kelompok eksperimen dengan mean rank kelompok kontrol sebesar 18.50, yang berarti bahwa ada peningkatan yang sangat signifikan kemampuan perencanaan karier siswa pada kelompok eksperimen setelah diberikan layanan informasi karier dibanding dengan kelompok kontrol.

Berdasarkan hasil uji hipotesis diketahui bahwa ada peningkatan yang sangat signifikan kemampuan perencanaan karier melalui layanan informasi karier, yang ditunjukkan dari hasil uji beda $\mathrm{p}=0.000<0.050$. Selisih mean rank antara pretest dan posttest pada kelompok eksperimen yaitu sebesar 18.64, sehingga dapat diketahui bahwa ada pening- 
katan mean rank setelah diberikan layanan informasi karier. Sedangkan selisih mean rank antara kelompok kontrol dengan kelompok eksperimen sebesar 18.50, yang berarti bahwa ada peningkatan yang signifikan antara kelompok kontrol dan kelompok eksperimen dalam kemampuan perencanaan karier setelah kelompok eksperimen diberikan layanan informasi karier. Hasil penelitian yang dilakukan peneliti menyatakan bahwa melalui layanan informasi karier dapat meningkatkan kemampuan perencanaan karier siswa, sejalan dengan hasil penelitian yang dilakukan oleh Ummah (2012) yang menyatakan bahwa penerapan layanan informasi karier dapat meningkatkan kemampuan perencanaan karier siswa kelas XII SMAN 1 Krembung Sidoarjo. Hasil penelitian ini juga sejalan dengan penelitian yang dilakukan oleh Retno (2012) yang menyatakan bahwa layanan informasi karier efektif untuk meningkatkan kemampuan perencanaan karier pada siswa kelas X SMA Negeri Wonogiri.

Layanan informasi karier diberikan selama 8 kali pertemuan, layanan informasi karier merupakan layanan yang diberikan kepada siswa untuk membantu siswa mendapat pengetahuan serta pemahaman tentang dirinya sendiri dan mengenai karier yang meliputi informasi tentang Perguruan Tinggi, dunia kerja serta syarat-syarat yang diperlukan sehingga siswa mampu merencanakan dan menentukan keputusan yang tepat untuk kariernya. Jadi, dari layanan informasi karier tersebut dapat membantu siswa memahami dirinya dan untuk mendapat berbagai keterangan, data, fakta tentang lingkungan

Tabel 5 Hasil Analisis Uji Mann Whitney Posttest Kelompok Kontrol dan Kelompok Eksperimen

Mann-Whitney Test

Ranks

\begin{tabular}{|c|c|c|c|c|}
\hline & kelompok & $\mathrm{N}$ & Mean Rank & Sum of Ranks \\
\hline \multirow[t]{3}{*}{ posttest } & eksperimen & 19 & 28.00 & 532.00 \\
\hline & kontrol & 18 & 9.50 & 171.00 \\
\hline & Total & 37 & & \\
\hline
\end{tabular}

Test Statistics

\begin{tabular}{|l|r|}
\hline & VAR00001 \\
\hline Mann-Whitney U & .000 \\
Wilcoxon W & 171.000 \\
Z & -5.197 \\
Asymp. Sig. (2-tailed) & .000 \\
Exact Sig. [2*(1-tailed & $.000^{\mathrm{a}}$ \\
Sig.)] & \\
\hline
\end{tabular}

a. Not corrected for ties.

b. Grouping Variable: VAR00002 
yang meliputi dunia pendidikan dan dunia kerja. Berbagai informasi dan pemahaman tersebut membantu siswa dapat merencanakan kariernya dengan matang.

Pandangan Williamson (dalam Winkel dan Hastuti, 2006) mengemukakan bahwa seseorang dapat merencanakan atau menentukan pilihan karier yang cocok baginya dengan mengkorelasikan kemampuan, potensi dan wujud minat yang dimilikinya dengan kualitas-kualitas yang secara obyektif dituntut bila memegang pilihan karier tersebut. Terdapat faktor yang mempengaruhi dalam perencanaan karier yaitu faktor internal dan faktor eksternal. Faktor internal ini merupakan informasi tentang diri sendiri yang meliputi kemampuan intelektual, bakat dan minat, sifat-sifat kepribadian, nilai-nilai kehidupan dan keterampilan khusus. Sedangkan faktor eksternal meliputi informasi tentang lingkungan (keluarga dan lingkungan hidup yang relevan bagi perencanaan karier khususnya informasi pendidikan dan informasi jabatan).

Adanya faktor-faktor tersebut, maka siswa perlu diberikan layanan informasi karier untuk mendukung siswa dalam merencanakan kariernya. Layanan informasi karier diberikan untuk membantu siswa memperoleh informasi tentang dirinya dan tentang lingkungan keluarga maupun lingkungan hidup yang relevan bagi perencanaan karier, sehingga siswa mampu membuat perencanaan karier yang matang. Hal ini berkaitan dengan apa yang dikemukakan oleh Hartono (dalam Yeni dan Nursalim, 2013) bahwa informasi karier sangat berguna untuk memperoleh pemahaman karier, perencanaan karier, menentukan alternatif pilihan karier dan melakukan evaluasi terhadap alternatif pilihan karier. Sedangkan menurut Prayitno dan Amti (2009), tujuan diberikan layanan informasi karier yaitu yang pertama untuk membekali individu dengan berbagai pengetahuan tentang lingkungan yang diperlukan untuk memecahkan masalah berkenaan dengan lingkungan sekitar, pendidikan, jabatan maupun sosial budaya. Kemudian yang kedua, memungkinkan individu dapat menentukan arah hidupnya termasuk rencana karier, dan yang ketiga yaitu memungkinkan individu dapat mengambil keputusan dan bertindak sesuai dengan aspek-aspek kepribadiannya.

Berbagai informasi yang didapatkan melalui layanan informasi karier tersebut juga berkaitan dengan apa yang dikemukakan oleh Parsons (Gibson dan Mitchel, 2011), yang menyatakan bahwa dalam merencanakan karier ada langkah yang harus dilakukan untuk membuat suatu perencanaan karier. Langkah tersebut yaitu pengetahuan dan pemahaman diri sendiri, pengetahuan dan pemahaman dunia kerja, kemudiaan penalaran yang realistis akan hubungan pengetahuan dan pemahaman diri dengan pengetahuan dan pemahaman dunia kerja. Sehingga, layanan informasi karier sangat mendukung siswa dalam membuat perencanaan karier yang matang, karena melalui layanan informasi karier tersebut dapat membantu siswa memperoleh pengetahuan dan pemahaman tentang dirinya sendiri dan dunia kerja. Kemudian dari pengetahuan dan pemahaman tentang diri serta dunia kerja, dapat melakukan penalaran yang realistis dengan menghubungkan pemahaman diri dengan pemahaman dunia kerja sehingga siswa dapat menentukan rencana karier secara matang dan bisa mencapai tujuan karier yang diharapkan.

\section{SIMPULAN}

Ada pengaruh yang signifikan layanan informasi karier terhadap kemampuan perencanaan karier siswa kelas XI SMA Negeri 2 Cepu. Hal ini dibuktikan dari hasil analisis Mann Whitney diperoleh $Z=-5.197$ dan Asymp.Sig.(2-tailed) $p=0.000<0.050$, artinya 
ada perbedaan yang sangat signifikan antara kelompok eksperimen dan kelompok kontrol. Mean rank kelompok eksperimen setelah perlakuan meningkat sebesar 18.64 dan selisih dengan kelompok kontrol sebesar 18.50

\section{SARAN}

\section{Bagi Subjek Penelitian}

Bagi subjek penelitian khususnya siswa kelas XISMA Negeri 2 Cepu diharapkan dapat lebih memanfaatkan sebaik-baiknya layanan Bimbingan dan Konseling. Melalui layanan bimbingan karier siswa akan lebih terarah dan terbantu dalam meningkatkan kemampuan perencanaan kariernya, karena perencanaan karier sangat penting untuk menentukan karier di masa depan. Perencanaan karier yang matang, siswa akan bisa menentukan pilihan karier yang tepat sesuai dengan dirinya dan bisa mempersiapkan dirinya untuk mencapai karier yang diharapkan.

\section{Bagi Pihak Sekolah}

Guru BK di sekolah lebih meningkatkan layanan Bimbingan dan Konseling secara intensif, dan layanan yang diberikan kepada siswa diharapkan sesuai dengan kebutuhan dan karakteristik siswa yang khususnya dalam hal perencanaan karier. Selain itu, layanan yang diberikan diharapkan dengan menggunakan berbagai metode yang variatif, sehingga siswa lebih tertarik untuk mengikuti kegiatan layanan Bimbingan dan Konseling.

\section{Bagi Peneliti Selanjutnya}

Bagi peneliti selanjutnya yang tertarik untuk penelitian yang sama, diharapkan dapat menambah atau memperluas ruang lingkup penelitian dengan menggunakan variabelvariabel lain yang memungkinkan dapat meningkatkan atau mempengaruhi kemampuan perencanaan karier. Selain itu, peneliti selanjutnya diharapkan melakukan penelitian dengan subjek yang berbeda.

\section{DAFTAR PUSTAKA}

Anggraeni, Fransisca D.N. 2012. Peningkatan Prerencanaan Karier Melalui Bimbingan Kelompok Pada Siswa Kelas X-BB SMK Sudirman 1 Ambarawa Tahun Pelajaran 2011/2012. UKSW (Skripsi tidak diterbitkan).

Azwar, Saifuddin. 2011. Penyusunan Skala Psikologis. Yogyakarta: Pustaka Pelajar.

Dessy dan Nursalim. 2002. Pengaruh Layanan Informasi Studi Lanjut Terhadap Kemantap-an Pengambilan Keputusan Studi Lanjut. Unesa.http:// ejournal.unesa.ac.id/index.php/ jurnal_ppb/article/view/5402 diunduh 8 September 2013.

Gibson dan Mitchell. 2011. Bimbingan dan Konseling. Yogyakarta: Pustaka Pelajar.

Prayitno dan Amti. 2009. Dasar-dasar Bimbingan dan Konseling. Jakarta: PT Asdi Mahasatya.

Retno, Selvia. 2012. Efektivitas Layanan Informasi Karier Untuk Meningkatkan Kemampuan Perencanaan Karier Pada Siswa Kelas X di SMA Negeri Wonogiri. http://digilib.fkip.uns. ac.id diunduh 14 Juni 2013.

Ummah, Mukhtarul. 2012. Penerapan Layanan Informasi Karier Untuk Meningkatkan Kemampuan Perencanaan Karier Siswa Kelas XII SMAN Krembung Sidoarjo. Unesa (Skripsi tidak diterbitkan).

Walgito, Bimo. 2010. Bimbingan Konseling [Studi \& Karier]. Yogyakarta: Andi.

Winkel dan Hastuti, Sri. 2006. Bimbingan dan Konseling di Institusi Pendidikan. Yogyakarta: Media Abadi. 